\title{
Exploration of Masculinity in Sanjeev Upreti's Hansa*
}

Indira Acharya Mishra

Associate Professor of English

Mahendra Multiple Campus, Dharan

indiraacharya42@gmail.com

\begin{abstract}
Can a man be rigid, strong and decisive all the time? How do people know about their normative gender roles? Who formulates the rules about love, sex, marriage, and men and women relations? These are some of the issues raised in Sanjeev Upreti's latest novel Hansa [Duck] (2019). The novel artistically and sensitively traces the limits of patriarchal gender roles and suggests that masculinity is contextual and undergoes a continuous process of change. The major male characters of the novel, despite their inclination towards heterosexuality, and despite their effort to perform traditional masculinity, fail. Though they have embraced hegemonic masculinity as an ideal form of masculinity, and try to practice it, they are weak and vulnerable. This article explores why these characters fail to perform their gender roles as par their expectations. To analyze male gender roles and masculinity in the novel, theories of masculinity are drawn basically from Raewyn Connell and Judith Butler's social constructivist approach to gender studies. Analyzing the novel through the lens of masculinity helps the reader understand the constraints of hegemonic masculinity and provides insight to alternative ways of understanding male gender roles and masculinity. The article has found that the male characters of the novel suffer because they stick to the traditional masculinity and fail to adapt to their changed roles.
\end{abstract}

Keywords: Gender roles, hegemonic masculinity, identity, masculinity, patriarchy.

\footnotetext{
"Received: March 31, 2020

Peer Reviewed: July 3, 2020

Accepted: September 2, 2020
} 


\section{Background}

Sanjeev Upreti has a unique place in Nepali literature. He is a versatile writer who simultaneously writes both fictions and non-fictions. Ghanachakkar [Turmoil], Siddhantakaa Kuraa [Discourse of Theory] and Makaiko Arkai Kheti [A Different Cultivation of Maize] are some of his published works. He marked his entry in Nepali novel with the publication of Ghanachakkar which secured his place in the field of Nepali novel as an experimental novelist. Likewise, Siddantakaa Kuraa established him as an expert in the Western philosophy and Makaiko Arkai Kheti shows his skill as a playwright. Besides, he writes regularly in Nepali weeklies and dailies. His newspaper articles reveal his gender sensitivity and have established him as a gender critic. His popularity as a gender sensitive writer is heightened with the publication of his second novel Hansa. This novel is exemplary in the history of Nepali experimental fiction. With the usage of embedded narratives, the novel tells stories which are open ended and have layers of meanings. These tales highlight multiple perspectives for understanding gender identity by deconstructing the human-centric, patriarchal understanding of gender roles.

To deconstruct the patriarchal notion of gender identities, Hansa, simultaneously, tells the stories of human and non-human beings. These stories explore male-female relations in their respective worlds. Narrated by plural narrators that include men, women and non-human beings, these stories deconstruct the human-centric discourse on love, sex, marriage and gender identities (Adhikari para. 1; Lohani para. 17). Prem, the protagonist of the novel, who narrates his tragic love story through memory and reminisces, reflects upon his failed conjugal life. Likewise, the male-female relations in the non-human worlds narrated by the female narrator, the owner of the local eatery, whose perspective dominates the narration revels different aspects of love. The woman perspective helps Prem look men-women relations from different angles. He realizes that men are constrained by patriarchal norms and values that dictate them to assert possession and authority over women. The way Upreti explores males' psychology and deals with the suffering of these characters in the novel provides background for the study of masculinity in the novel.

\section{Problem, Objectives and Methodology}

Prem's initial resolution is to murder his wife's second husband, Anuj. As he recalls the phone call made by Anuj, he reinforces his decision to behead him. Because Anuj has challenged his masculinity: first by taking his wife away from him, and second, by asking for an appointment with him. It is a sheer humiliation for Prem's manhood. He wonders how the villain has dared to meet with the person whose wife he has taken away. Traditionally, in the Nepali society, the jāra, the person with whom one's wife elopes, is taken as the greatest enemy for the husband. Thus, to avenge Anuj, he accepts the appointment and goes to meet him 
carrying a bhojapure khukuri in his bag. He recalls the scene vividly, the shining neck of Anuj, his own sweaty hand clutching the handle of the knife, and his resolve to complete the task as soon as possible. His foe is alone and unarmed; he looks tired, and if Prem has made an attempt he could have completed the task within no time. Yet he delays; and finally, he even gives up the idea of murdering. The way he gives up the very thought of revenge does not match with his resolution; it is unmanly compared with his initial resolution.

In the same way, Anuj, and other male characters, too, behave in opposition to readers' expectation. Though they are men and expect to perform masculine gender roles, they fail to do so. This creates problematic for the study of the male characters in the novel to know why these people, though they are men, fail to showcase their masculinity and keep their masculinity intact till the end. In this endeavor, the study seeks answers to the following research questions:

- What gender roles are assigned to the male characters in the novel?

- How do they showcase their masculinity?

- Why do they fail to keep their masculinity intact?

The main objective of the article is to analyze the male characters to trace their gender roles and examine the way they articulate masculinity. For this, the study, primarily, takes theoretical insights from gender critics like Raewyn Connell and Judith Butler who propose a social constructivist approach to gender. These critics argue that gender is socially, culturally and historically specific rather than biologically or naturally fixed entity. Following constructivist approach to gender, this study believes that gender is fluid and changes over time and space; and gender roles and expectations also vary according to time and space. From this premise, masculinity is seen not essential or immutable; it is neither a biological truth nor can it be defined or judged according to a set of fundamental characteristics. Todd W. Reeser suggests that "to study masculinity we have to examine how it is articulated" (29). Masculinity is not predetermined or inherent aspect of males. Thus, to understand masculinity one needs to analyze how they express themselves in the given time and space.

Connell explains that although "gender is social practice that constantly refers to bodies and what bodies do, it is not social practice reduced to the body. . . gender exists precisely to the extent that biology does not determine the social" (Masculinities 71). This means that gender relations and gender identities reach beyond the reproductive sphere. Connell, thus, emphasizes the distinction between the social and the biological in the ordering of gender relations. There is no simple acceptance of one form of gender and rejection of the other. Rather, there are multiple displays of what has been termed masculinity and femininity in any society, organization and even individual. 
To further the notion of multiple displays of masculinity, Connell puts forward the notion of hegemonic masculinity. The concept of 'hegemonic masculinity' emphasizes that many variations on the concept of 'masculinity' exist within and between societies. Connell claims that although there are many ways of being a man, some are valued more than others; and men experience social pressure to conform to dominant ideas about being a man (The Men and the Boys 86). Caroline Sweetman agrees: "In each community, a particular form of masculinity will be widely perceived as the most desirable, and as wielding the most power - a 'hegemonic masculinity'. Because hegemonic masculinities define successful ways of 'being a man', they make men who do not conform to that idea seem — and feel — inadequate or inferior" (5). Obviously, hegemonic masculinity that by its nature as socially constructed it may also be reconstructed; and it is the pattern of practice that legitimatizes men's dominance over women.

Accepting these premises has clear consequences for one's understanding of what masculinity is. Masculinity is not essential or immutable, neither all men are masculine. And, though under patriarchy 'hegemonic masculinity' is seen as the ideal form of masculinity, not all men manage to perform them every time. This analysis of Upreti's Hansa is based on these premises about masculinity.

\section{Review of Literature}

Upreti has received a great deal of critical acclaim for this novel. Reviews and comments of the book are published in the Nepali national dailies and weeklies as soon as it was published. Similarly, a host of literary reporters have interviewed Upreti about his writing inclination and the novel. To facilitate the analysis, this section reviews the reviewers, readers and critics' opinion about the text.

At the threshold of its publication, the editor of Setopati Online newspaper talked to Upreti's about Hansa. Upreti assured him that the novel would be the mixture of realism and surrealism. Upreti confessed that he had tried to see the world from nonhuman perspectives and tried to include the issues of masculinity, femininity, environment and immigration (para. 1). Likewise, in his interview with the reporter of Shilapatra Upreti points that there are layer of meanings in the novel. The primary story of the novel has straight flow; but the other substories create layer of meanings and it depends on the individual readers how they explore those layers (para. 11). In the same way, Rajkumar Baniya, a literary critic based on Nepal magazine, reports Upreti's views on the novel. Baniya mentions that the novel deals with the stories of humans, birds and animals. The novel critically examines the discourse of love, gender identity, environmental crisis and the problem of immigration (para 2). All these reviewers have dealt with the themes of the novel.

Similarly another literary critic Bibek Adhikari observes that the novel is an example of environmental literature. Juxtaposing realism and surrealism, the novel portrays a myriad of 
issues - from diaspora experience to anthropomorphism to human sentimentality. Adhikari focuses on the two plots of the novel that deal with the stories of Prem and the whimsical duck. He argues that "by writing the stories of birds, snakes, and other animals and personifying their experiences, the writer has displaced an anthropocentric narrative and given due importance to marginalized stories" (para. 7). However, Adhikari cautions the reader not to misinterpret the novel merely as a story of birds and animals.

Ram Lohani, another critic of Nepali literature, praises the new taste provided by Hansa. He ensures that the novel is sure to earn huge readership. Lohani argues that Hansa is a philosophical novel that reflects upon the significance of spinning stories in human life. A story is a phenomena or the reflection of lived experience, not the experience itself. However, no story is complete and has final message. This aspect is highlighted in the novel. The novel tells the stories of man and duck from their own perspectives. But one who can analyze things from the perspective of others may reach closer to the truth. According to Lohani, the novel reveals that not only the human have stories but animals also have stories of love and separation. But because of the limitation of human language man fails to understand non-human beings. Similarly, because of ego and the assertion of ownership in love and relation men experience tragedy in their relations (para 17). These critics focus on the nonhuman world the novel depicts.

In Loktantra Post, Mayamitu, claims that Hansa encompasses everyone's story. She points that the novel deals with the issues of environment. The novel shows that human beings are the cause of environmental degradation and it is their responsibility to keep the environmental balance to ensure the existence of both humans and nonhumans (para. 1). Rajani Dhakal, an academician, also believes that the novel is about the correlation between human and nature (para. 1). Whereas, Sushma Barali, a news reporter based on Himalkhabar in her interview with Upreti claims that Upreti has challenged human knowledge about themselves and other beings in the novel. In this text birds and animals also share their feelings about love and romance. They are empathetic and considerate towards the others. But human beings are selfish and they impose their whims on others and try to control and dominate them. For the continuity of the earth, there should be co-existence among human beings, non-human beings and the nature (para 8-9). These reviewers, too, focus on the nonhuman world the novel deals with.

In the same line of reading, Nirvikjung Rayamajhi of Sumparna Weekly interviews Upreti about the relations between nature, humans and animals and the position of environmental literature. Upreti observes that non-Western countries are more eco-friendly as they worship nature and protect nature (para. 1). Upreti also shares his inclination to nature and his love for 
birds. He suggests that people have different interests; and we should value each one's life style and interest if the individual is honest and lives with self-esteem.

Aswani Koirala, too, has interviewed Upreti about this novel. Koirala believes before the publication of this novel, Nepali novels generally put human characters at the center; but this novel is written from the perspective of ducks. Seen from their perspectives the novel exposes the absurdities of human life. In the interview, Upreti also suggests that feminism and masculinity studies do not oppose one another. Rather they align to each other. Masculinity studies shows that patriarchy does not only harm women; but it harms men as well. Men are pressurized to earn name and fame. They have to be economically successful to meet the needs of their families. Because of these social pressures, they suffer from tension and diseases. These issues are explored in the novel. Thus, both masculinity studies scholars and feminists should work together for the betterment of human beings (para 22). Here are some hints at the gender roles in literary creations.

These critics have reviewed the different aspects of the novel. They all agree that the novel is unique as it deconstructs the human centric approach of novel writing. Similarly, they agree that the novel raises the issues of environment, immigration, and gender identity. These opinions help to have a good understanding of the novel. However, there has been no in-depth study of Hansa from masculinity studies perspective. Thus, this article endeavors to fill this research gap in the discussion section.

\section{Exploration of Masculinity in Hansa}

Using the technique of flashback and foreshadowing, the plot of the novel, Hansa unfolds with its protagonist, Prem, recalling his resolution to behead his wife's second husband, Anuj Pande. Accordingly, he makes an appointment with him at Taudaha. In the local eatery at Taudaha, where he spends the night, he recalls his resolution to murder his jāra by beheading him. His memory, simultaneously, switches to the moments he has spent with Seema, to the narration of the jāra and stops to listen to the legends of Taudaha from the old woman, who owns the local eatery. These embedded narratives deal with the different issues of masculinity. These tales show that masculinity is a social constructed phenomenon; and male born individuals learn to be masculine through socialization. However, masculinity is not rigid and fixed; rather masculinity is fragile, provisional, something to be won and then defended, something under constant threat of loss. David D. Gilmore reverentially states that "real manhood is "a precarious or artificial state that boys must win against powerful odds" (11). Indeed, masculinity means "more than just being a man" (Synnott 22); and men have to prove their masculinity for social acceptance.

At first Prem gets surprised to receive the unexpected call from Anuj, his jāra. He wonders how the villain has dared to call him. But, listening to his distorted voice, Prem 
assumes that Anuj must have been drunk. There is an interrelationship between alcohol and male gender role ideology. Donald R. McCreary observes that men, who strongly identify with the hegemonic definition of masculinity and consider their own masculinity as threatened, are disposed towards using and abusing alcohol (468). Prem estimates that Anuj must have been an audacious man to take his wife and then desire to talk to him. Otherwise, he would not have called him. Then he decides to meet him, to deny the appointment would be a cowardice activity from his part. He reflects:

je hos, usale nai phona garepachi nabhețne kurai bhaena. maile bheța aswīkāra gare daräera bhetna mānena bhanna sakcha. [Anyway, since he has called to meet, there is no question of denying. If I denied, he might tell that I was afraid of meeting him]. (58)

Thus, in order to prove his manliness, he readily accepts the appointment and goes to Taudaha, the place where he has shared romantic moments with Seema. He cherishes those moments; so, it would be the appropriate place to avenge him.

Prem is determined to murder Anuj for he has snatched his wife away from him. It would be an insult to his manhood to compromise with his jāra. So, he carries a bhojapure khukurī (a typical Nepali knife) to behead the jāra. Indeed, traditionally, Nepali people believe that the jāra is the greatest enemy of a man. Turner and Turner mention that when the husband has killed the adulterer, jāra with his khukurī, he proclaims openly in the village 'jār kate' and displays the blood-stained khukurī. This proclamation saves him from accusation of murder (215). Though it is a crime now, grown up in the traditional patriarchal Nepali society, Prem must have internalized the traditional masculine traits ascribed to men. As a man he needs to act like a man by being aggressive, decisive and rigid; his decision to murder the jāra with the khukurī reveals his understanding of male gender roles. A man should accept the challenge.

Prem believes that he should be victorious. Thus, being fully armed with the sharp khukurī he goes to confront his jāra. Louis Tyson aptly comments that "men are not permitted to fail at anything they try because failure in any domain implies failures in one's manhood" (87). Prem recalls: "tyasaile jārako ghẫ̄̄ chapkāune bhanerai dhārilo bhojapure khukurī jholāmā lukāì tyo dina ma Taudaha pugeko thiẽ [Thus, to behead the jāra, that day I reached Taudaha hiding a sharp khukurī in my bag"]. After deciding to murder his jāra, he tries to visualize the romantic moments that he and Seema have shared. But he can only visualize the injuries of Seema's face: her swollen face, blood smeared lips and blue marks over her face. Vision of Seema's wounded face reminds him the echo of Rastriyabadi's satiric insult to his identity as a man: "thuikka lāchī [disgusting coward"] (59). Rastriyabadi abuses him for being effeminate as he financially depends on his wife. 
Under patriarchy male individuals are groomed to play the role of a provider and protector for their family. Prem also expects to perform the role of a breadwinner for his family. Anuj's father also insists on the importance of these roles for men. His father would remind him that a man should earn both name and fame. According to him, one who fails in these matters would be useless:

nāma ra dāma kamāuna nasakne lognemānche paśusaraha hunch. . . tyastā pānīmaruwāko jīvan kukura-birālāsaraha hunch. [A man's life would be like that of animals if he fails to earn name and fame .... such effeminate men's life would be like that of dogs and cats]. (79)

Anuj's father would beat and discipline him to make him studious so that he would be able to perform his gender role appropriately. Prem has also internalized patriarchal belief system; but he fails to get a stable job. Neither he has inherited business nor has a professional legacy. Consequently, he has the status of a dependent husband. Connell argues that "becoming a gendered person follows many different paths, involves many tensions and ambiguities, and sometimes produces unstable results" (Gender 6). Failure to play the role of a provider has debilitating effect in his sense of being a man. Thus, he takes solace in alcohol. Paradoxically, drinking alcohol is one criterion of articulating masculinity as Russell Lemle and Marc E. Mishkind argue that "Drinking is not merely permitted; it is prescribed as a means of affirming masculinity" (213). Though Prem fails to prove his masculine identity through economic independence, he asserts it drinking in the company of his male friends.

Men in patriarchy think that wives are their property and they should protect and control them. One's masculinity is confirmed by his capacity to sexually satisfy his wife and impregnate her. Since women chastity is a highly valued virtue, the husband will be blamed for failing to satisfy or control his wife, in case she has extra marital affair. Jack Sawyer maintains that "men who fail to be dominant are the object of jokes, scorn and sympathy from wives, peers, and society in general" (25). Rastriyabadi's questioning Prem's potency and his wife's chastity challenge his masculinity:

kamāu swāsnīle kati dina pālos kabilāi? khoi bihā bhaeko tīna barșamā pani bāu banna sakinas. abata sodhne nai belā āeko cha, katai tero hatiyārale kāmai nagarne ta hoina? tyasai ho bhane Sìmajī ekadina bepattā, ani kabijyū eklai jạ̣̃̂a ghutkyãudai biyogakā kabitā lekhna thālnechan. [How long does an earning wife feed the poet? It has been three years since you were married, yet you are not a father? Now it needs to be questioned whether your weapon is useless? If so, Seema would vanish one day and the poet would be writing tragic poems drinking all alone]. (99)

Prem is subjected to ridicule and mockery not only because he fails to play the role of a provider, but also to control his wife through sex. Rastriyabadi even doubts his potency as a 
man. David Leverenz aptly notes: "Across cultures and centuries, the erect penis has been the most basic synecdoche for a man's virility and force" (63). The word hatiyāra [weapon] is a euphemism for penis. This remark damages his public image as a man. It hurts his ego.

Rastriyabadi's scandalous remarks on Seema's character also show how men use women as a troop to ventilate their jealousy, aggression or other type of feeling. If they want to hurt a man, dishonor and shame him, they usually blame his wife or other female members of his family having loose morale. He instigates Prem:

hākimale shrīmatìlāì ochyāisakeko patto chaina. yastā nāmardasã̃ng ke kurā garnu? bhaigo, hutihārā samjhera māpha garchhu. [You are not aware of the fact that your wife has been sleeping with her boss. It is useless to talk to such an effeminate man. It is over; I forgive you believing that you are a coward]. (100)

Rastriyabadi uses Seema's character as a tool to belittle Prem. He insists that she has been sleeping with him and Prem is a coward to tolerate her. It is an open threat against his masculinity. Gilmore explanation rings true to Prem's case: "Manhood certainly does not appear to be self-reliant and autonomous. On the contrary, masculinity seems to depend chronically on the estimation of others, to be highly vulnerable to attack by ridicule, shaming, subordination, or 'dishonorable' female action" (17). Prem echoes: "nāmarda, nāmarda, arkāsãnga salkekī swasnīko paisāmā moja garne nāmarda [you are an effeminate man for you enjoy on the money of your wife who sleeps with another man"] (101). Indeed, women's unlicensed sexual relation is a threat to male prestige. To admit publicly that his woman had been unfaithful would be to undermine his masculinity. Consequently, Prem aggressively reacts to the insult. Forgetting all his duties and responsibility to his wife, he beats her mercilessly. Because of the domestic violence Seema leaves him.

Violence is commonly practiced by men to tame and control their wives. Fear of and control over female sexuality lead men use violence against women (Khan 7). Memory of Rastriyabadi's insult to his masculinity drags Prem back to the lane of his conjugal life with Seema and then to his childhood days. He vividly recalls the scene of his jealous father beating his mother in the charge of adultery:

$\bar{a} m \bar{a}$ roeko āwāja tyataibāta āũdai thiyo, pahile dhyāma- dhyāma āwāja āyo, tyaspachi àmāle 'mare ni' bhanera karāeko, bwāle țhūlațū̄lo swaramā amāckārī gālī gareko. [Sound of mother's crying was coming from that very direction, first the sound of punching and thrashing, and then the sound of mother yelling and father abusing her with unbecoming words]. (44)

Prem realizes that it is not fair. Thus, he avoids talking to him as a protest. Instead of being guilty, his father reminds him saying that as a grown up man one should know how to control 
his wife. He further proudly informs Prem that his grandfather had three wives under his control. The underlying meaning of his father's remark is that a man needs to beat his wife to prevent her from being wayward. This belief triggers him to indorse the use of violence upon his wife.

Revenge motive is another masculine motive that patriarchy installs in people with male body. Prem hides the Bhojpure khukurī in his bag to behead Anuj. He is guided by the thought that women are objects for men's sexual gratification; and a man needs to satisfy his wife sexually. Feelings of how Anuj might have enjoyed Seema's body and ridiculed his masculinity by listening Seema's bemoaning with ecstasy intensify his fury:

jārale merī Sìmāko śarīralā̄ kasarī sumsumyāyo holā ? maile cumekā rasilā oṭamā kasarī āphno mukha jotyo holā? usakā bhūgolakā khocaharūmā kasarī luțupuṭu bhayo holā ? Sìmāle ānanda utkarșamā sitkāra gardā mero puñsatwako upahāṣa gardai kasarī hã̃syo holā? yastai anekan praśna manamā umlirahanthyo. lāgthyo jāralāi kātepachi mātra mana śānta hunecha. [How has the jāra played with my Seema's body? How has he pushed his mouth in the juicy lips that I have kissed? How had he caressed the valleys of her geography? How has he insulted and laughed at my masculinity when Seema bemoaned in ecstasy? Different questions like these would broil in my mind. I thought I would be calm only after killing the jāra]. (5)

Prem believes that Seema's body belongs to him. Thoughts of someone else enjoying his wife madden him. He hopes to pacify himself after retaliating his enemy.

Traditionally, male gender roles include bread earner and protector of the family. Similarly, men are expected to be aggressive, dominating and courageous. Gender critics argue that playing the traditional gender roles promotes men power and legitimize men's exploitation of women as sexual objects. But Connell points that traditional gender roles harm men as well because they need to prove their superiority and not withdraw from fight and argument. As a result they "get beaten and sometimes even murdered" (Gender 4 ). Because of the internalization of masculine gender roles Prem behaves aggressively in the bar, beats his wife and determines to murder Anuj.

Moreover, gender scholar believes that individuals' gender identities are ongoing, lifelong phenomena which are never finished; they are socially constructed, negotiated and performed; they are unstable and shifting; they are frequently contradictory; and different identities can be, and often are, adopted at different times. Connell argues:

Being a man or a woman, then is not a pre-determined status. It is a becoming, a condition actively under construction. The pioneering French feminist Simone de Beauvoir, puts this in a classic phrase, 'one is not born, but rather becomes a woman.' 
Though the position of women and men are not simply parallels, the principle is also true for men; 'one is not born masculine; but has to become a man.' (Gender 5)

Connell argues that one is not born masculine but one has to become a man to be socially acceptable. Prem has been encouraged, disciplined and coerced to adopt masculine gender roles. Rastriyabadi's insult is an example of how someone who fails to do his gender properly becomes the subject of ridicule.

Gender is, thus, continually performed and re-performed; and in this way gendered identities are constructed. The so-called '"performative accomplishment' is kept in place by both the social sanctioning of certain behavior and the labelling of taboos. It is the repetition of a performance and the ritualizing of them ensure that certain behaviors and expectations are legitimized" (Butler 520). Though Prem fails to perform the role of provider, he showcases his masculinity dominating and controlling his wife. But he suffers from separation as Seema has flown to America without informing him. He loses his control over her.

Chivalry and gallantry are other traits traditionally associated to men as prerequisites to attract women. Fed with the patriarchal notion of manhood, Anuj thinks that he should rescue Seema from the clutches of Sher Singh, the villain. Hence he warns him not to look at her with his leering eye. As a Nepali man he is capable to protect a Nepali woman from being exploited by a foreigner. Besides, as a young man, despite being married and having a wife back at home, he asserts his masculinity by offering his love and company to her. He impregnates her and takes the responsibility of a husband and would be father by registering his marriage in the court. These different activities of Anuj insure his masculinity. But he cannot continue showing the same vigor and courage to keep his masculinity intact. Prem has expected that his jāra would be a man of chivalry and gallantry since he has wooed Seema. Anuj's tired and lethargic look contradicts his expectation. Prem wonders how such effeminate man could have lured his beloved. He doubts her choice.

Traditional gender roles cast men as rational, strong, protective, and decisive. Prem's resolution to murder his jâra supports this. Nonetheless, despite his being armed he postpones his decision. He analyses the reason why he has refrained from killing Anuj: "tara tyasa bela ta ma kathākārmātra thiinã, euțā puruṣa pani ta thiẽ, jaskī patnīle parapuruṣalāà ãgāleki thī̄. [But, at that time I was not only a story writer, but also a man, whose wife had been in relation with another man"] (97). He assumes that his personality as a writer might have prompted him to listen Anuj's story. Nonetheless, he assures himself that he is a man whose wife has taken another husband; and as a man he must avenge his foe.

jholāmā raheko bhojapure usako gardhana chināuna tamtayār thiyo. tara najāne kina ho, khukurīmā mero pakaḍa kamajora hüdai thiyo. ū ugra ra ahañkārī dekhieko bhae 
maile māra hanisakthe. tara usalā̄ ta maile āphūbhanda pani du:khī ra galeko dekhe. [The Bhojapure khukurī was ready to chop his head off. But, I do not know why my control over the khukurī was being weakened. If he had looked aggressive and vain, I would have beheaded him. But I found him more miserable than me]. (75)

Prem has expected that Anuj would be a reckless and vain person who would not give up without fighting. But he finds him helpless, not worth fighting. Despite being armed his determination is fading. His behavior suggests that masculinity is fluid and situational.

Anuj narrates, in detail, about him and Seema and also tells the stories of other men, Ram Karki, Sher Singh, and Ashraf Bhai, as parts of his own story. Their stories also reveal that there is no single masculinity and thus no single response. Yet, while there is no single monolithic masculinity, certain traits are considered the norm, accentuating what the performance of 'proper' masculinity should entail. Although not all men may be in a position to assert hegemonic masculinity, there is an acute awareness among men of this construct. Though these men have embraced the traits associated to hegemonic masculinity as the norm they fail to articulate them in their daily life. As people of the third world Ram Karki, Sher Singh, and Ashraf Bhai, like Anuj, they have been living a hard life in America to meet their masculine gender roles as bread earners. The compulsion to earn more has led them to America. Traditionally, a man's masculinity is measured in terms of his material gains. People believe that gender distinction into men/women is natural. Accordingly, they accept the social arrangements like jobs, sports, marital rules and like that. "Belief that gender distinction is natural makes it scandalous when people do not follow the pattern" (Connell, Gender 5). Thus, to meet the demands of their gender, they have illegally immigrated to America. Unlike their expectation, however, they fail to keep their masculine identity intact in the land of other.

Connell's three-fold model of the structure of gender is particularly useful for analyzing the gender dynamics in the context of these people. Connell suggests that gender identities are defined in terms of division of labor, in terms of power relation and in terms of expression of desires or sexuality (Masculinities 74). Among them division of labor is instrumental to define one's identity. Sweetman affirms:

The sexual division of labour is a concrete expression of ideologies surrounding gender identity. The ways in which women and men respond to changes in the sexual division of labour (including patterns of employment and income generation) are directly connected to their sense of themselves as gendered human beings. (5)

Hegemonic masculinity emphasizes men's role as economic providers and sees women as workers who perform unpaid domestic works. These men have internalized this notion and believe that cooking and cleaning in the kitchen are feminine jobs and are less respectful for men. They despise these works. But in the alien land, they are forced to do these jobs. 
Though these people fail to perform their masculinity in terms of the division of labor, they try to maintain their masculine identity in other ways. For example, Ashraf Bhai, who has migrated to America from India to meet his gender role expectation by earning money, and though he earns, he feels effeminate working in the kitchen. He fears that he might turn to female using feminine instruments all the time. Thus, to keep his masculine identity intact he has started growing his moustache: "ashrapha bhāiko bāklo jungā jananā bhaincha ki bhanne darabiruddhako rachyākawaca thiyo [Ashraf Bhai's thick moustache was the protective shield against his fear of being a woman"] (63). His thick moustache insures his masculinity. Though he has a wife and three sons back in India and meets his manly duty by sending golden jewels to his wife, he feels it inadequate for his gender identity. It shows how patriarchal imposition of hegemonic masculinity makes a man, who is unable to embrace the traditional notion of masculinity based on achievements, independence, aggressiveness and physical robustness, insecure and shaky about his own masculinity despite his heterosexual status and orientation.

Feelings of fear, vulnerability and self-doubt are debilitating to one's construction of masculinity. Connell explains: "We make our own gender, but we are not free to make it however we like. Our gender practice is powerfully shaped by the gender order in which we find ourselves" (Masculinities 74). Though Ram Karki, Ashraf Bhai and Anuj are men, Sher Singh abuses them as effeminate, impotent men for they lack green card and are illegal and powerless: "na tuma logakā grina cārḍa hai, na visā. sabake saba iligala ho, hijaḍe sāle [Neither you people have green card, nor visa, you are all illegal, you worthless impotent"] (67). He has maintained to get the card and feels more powerful than these people and tries to dominate them. But he, too, cannot maintain his manhood all the time. His single status makes him cry shedding torrential tears.

The way these people try to maintain their masculine identity supports the idea that one is not born masculine, but one becomes a man. They have embraced the male role-model of a bread earner imposed on them by the society along with the traits like aggressive, assertive and domineering and endeavor to articulate them in their day to day interaction to others. Anuj, for instance, confirms not only his heterosexuality by being married to two women and impregnating them but also with his role as a protector by interfering between Sher Singh and Seema. He warns him not to try for a Nepali girl. For Nepali men's blood is not made up of tomato sauce (66). His loud voice and warning support traditional notion about manly temper. His financial supports to his parents and these acts fit to traditional gender roles assigned to men.

However, with the arrival of Maya in America, despite his love for both Seema and Maya, he cannot perform his role as a husband of two wives. He is constrained by the American matrimonial law. He succumbs, "tara mānche bhaepachi ta samājakā niyama- 
kanūnale ghã̂tī nimothna äihālchan kyāra [But a man's throat is twisted by the rules and regulation of the society"] (131). Anuj realizes that a man cannot live as par his wishes. Being undecided he returns to Nepal without informing his wives. Then again, his father debars him from his house for his shameful unmanly deeds. Butler sounds true as she explains that people who fail to 'do' their gender correctly, or who do it in ways that accentuate its genealogy and construction are punished by culture and laws (273). Similarly, Prem loves Seema and has been in illusion that she will come to him sooner or later for they have not been divorced yet. But he is fated to listen to his wife's second husband. Despite their love for their spouses, both Prem and Anuj are rejected by their wives.

Obviously, as men, the male characters of the novel have internalized the role of provider and protector to their wives and other family members. But circumstances do not favor them and they cannot perform their masculinity in the desired way. Prem fails to get an honorable job: his economic dependence on his wife invites mockery and ridicule from his friends. When he fails to play the role of a provider, he takes refuse in alcohol and uses domestic violence against his wife to ascertain his masculinity. This leads to his catastrophe. Similarly, to accomplish the role of provider and protector, Anuj has gone to America where he marries Seema. But when Maya joins them, his situation becomes chaotic. The other male characters, too, though they meet their role of the provider by earning cash, doing feminine jobs, they feel belittle. As a result, their self-esteem crumbles.

\section{Conclusion}

The study reveals that issues of masculinity prevail in the novel Hansa. The novel explores the agony, pain and pressure experienced by men in patriarchy. The major male characters, along with the protagonist of the novel are assigned traditional male gender roles. As son, lover, husband and father, they have internalized patriarchal belief system; and they embrace their roles of provider and protector as natural. In the process of translating their belief system into actions, however, they suffer. To keep their masculinity intact, they struggle with no avail. These men suffer because they try to maintain the status quo; they are rigid and do not acknowledge the changes. The way these male characters perform their gender supports the constructivist approach to gender. This study has analyzed masculinity in Hansa. Future researchers can analyze the narrative techniques of the novel. They can also analyze it from the perspective of eco-feminism as well.

\section{Works Cited}

Adhikari, Bibek. "Hansa: Dismantling Myths at the Taudaha Lake." Kathmandu Post, https://kathmandupost.com/books/2019/11/09/hansa-dismantling-myths-at-the-taudahalake. 
Baniya, Rajkumar. "Sanjeevako Arkai Kheti" ["Sanjeev's Different Cultivation."] Nepal, https://nepalmag.com.np/profile/2019/09/24/20190924124123

Barali, Sushma. "Taudahakā Premila Hānsa" ["Lovely Ducks of Taudaha."] Himalkhabar, https://www.himalkhabar.com/news/15689.

Butler, Judith. Gender Trouble: Feminism and the Subversion of Identity. Routledge, 1990.

Connell, Raewyn. Gender and Power: Society, the Person and Sexual Politics. Polity Press, 1987.

---. The Men and the Boys. Polity Press, 2000.

---. Masculinities. Polity Press, 2005.

Connell, Raewyn W, and James W. Messerschmidt. "Hegemonic Masculinity: Rethinking the Concept." Gender and Society, vol. 19, 2005, pp. 829-59.

Dhakal, Rajani. "Prakriti Ra Mānavako Sahacetanāko Uḍāna" ["Flight of the Co-consciousness of Human and Nature."] Koselī, Kantipur, https://ekantipur.com/koseli/2019/11/02/15726698029547641.html?author=1

Gilmore, David D. Manhood in the Making: Cultural Concepts of Masculinity. Yale UP, 1990.

"'Ghanacakar'kā Lekhaka Sanjeev Upretiko Nayā Upanyāsa Hansa Āudai" [The Author of Ghanachakar, Sanjeev Upreti's New Novel Hansa is Coming."] https://www.setopati.com/art/art-activity/190636

Khan, Mehr, ed. Domestic Violence against Women and Girls. UNICEF, 2000. https://www.unicef-irc.org/publications/pdf/digest6e.pdf

Koirala, Aswini. "Purusamāthi Dherai Dabābacha, Adhyātmabhitra Jhan Kalaha Dekhe" ["Men are in Great Pressure, I Noticed More Quarrelling in Religion."] https://www.onlinekhabar.com/2019/09/799809

Lemle, Russell, and Marc E. Mishkind. "Alcohol and Masculinity.” Journal of Substance Abuse Treatment, vol. 6, no. 4, 1989, pp. 213-222.

Leverenz, David. "Aging Beyond Masculinities, Or, the Penis as Failed Synecdoche." Alternative Masculinities for a Changing World, edited by Àngels Carabí and Joseph M. Armengol, Palgrave, 2014, pp. 63-91.

Lohani, Ram. "Hansako Hansa" ["Duck's Consciousness."] Phursad, Annapurna Post, http://annapurnapost.com/

Mayamitu. "Hansa Sabaiko Kathā" ["Hansa is Story of All."] Loktantra Post, https://loktantrapost.com/?p=17602

McCreary, Donald R., and Stanley W. Sadava. "Stress, Alcohol Use and Alcohol-Related Problems: The Influence of Negative and Positive Effect in Two Cohorts of Young Adults." Journal of Studies on Alcohol, vol. 61, no. 3, 2000, pp. 466-474. 
Rayamajhi, Nirvikjung. "Sāhitya Lekhdā Sidāntako Hyāna Bokdina" ["I do not Carry the Hangover of Theory while Writing Literature."] Sampurna, https://sampurnaweekly.com/news/2930

Reeser, Todd W. Masculinities in Theory: An Introduction. Wiley-Blackwell, 2010.

Sawyer, Jack. "On Male Liberation." Feminism and Masculinity, edited by Peter F. Murphy. Oxford UP, 2004, pp. 25-27.

"Sidāntako Ghanachakkar bāta bāhiridai Sanjeev Upreti" ["Sanjeev Upreti is Coming out from the Turmoil of Theory."]

https://shilapatra.com/detail/11734?fb_comment_id=2368284306618496_2372513522 862241

Sweetman, Caroline, ed. Men and Masculinity. Oxfam GB, 2000.

Synnott, Anthony. Heroes, Villains and Victims. Ashgate, 2009.

Turner, Ralph Lilley and Dorothy Rivers Turner. A Comparative and Etymological Dictionary of Nepali Language. Adarsh Books, 2007.

Tyson, Luis. Critical Theory Today: A User Friendly Guide. 2nd. Routledge, 2008.

Upreti, Sanjeev. Hansa [Duck]. Book Hill, 2019. 